\title{
A Descriptive-Comparative Analysis of Apology Strategies: The case of Iranian EFL and Malaysian ESL University Students
}

\author{
Atieh Farashaiyan \\ Faculty of Social Sciences and Humanities \\ University of Kebangsaan Malaysia (UKM) \\ 43600, Bangi, Selangor,Malaysia \\ Tel: 60-17-327-6098 E-mail: atieh_farashaiyan@yahoo.com \\ Seyed Yasin Yazdi Amirkhiz (corresponding author) \\ Faculty of Educational Studies \\ University of Putra Malaysia (UPM) \\ 43400, Serdang, Selangor, Malaysia \\ Tel: 60-17-305-9737 E-mail: nasser_yazdi@yahoo.com
}

\begin{abstract}
This paper reports on a study that was carried out to describe and compare the apology strategies utilized by Iranian EFL and Malaysian ESL learners in confronting identical apology situations. For this purpose, data were elicited from 15 Iranian and 15 Malaysian students through a Discourse completion tasks questionnaire. The participants were of the same language proficiency. Results of the study showed certain similarities and differences in terms of frequency and typology of strategies used by Iranian and Malaysian students. The findings of this study might be of pedagogical help and significance to teachers, students and those interested in pragmatics in general and apology speech act in particular.
\end{abstract}

Keywords: Apology strategies, Typology, Frequency, EFL/ESL learners

\section{Introduction}

Among the speech acts we employ in our daily life and most of the situations, apology is one of the most frequently utilized speech acts. An apology is a face-threatening act (Brown and Levinson, 1987) that requires the speaker to admit the responsibility for some behavior (or failure to carry out some behavior) that has proved costly to the hearer. It is in a sense remedial action (Goffman, 1971) that serves to maintain, restore and augment the interpersonal relationship. Apologies are found in all human communities in that human being is a social creature and maintenance of harmony in one's interpersonal relationships is a socially warranted necessity. Apologies are realized in an assortment of patterns and clutch a specific cultural value and this state of variety lies in the fact that the social organization of human societies are in variation (Wouk, 2006).

Generally speaking, research literature in pragmatics has been dominated mostly by the studies which address the ways non-native speakers differ from the native speakers of the target language (e.g., Bardovi-Harlig, 2001), and this seems to be owing to the fact that native speakers of a language have been logically and traditionally regarded as the ideal reference of pragmatic knowledge and performance. However, with the emergence of new global realities such as native speakers of "English" being heavily outnumbered by "non-native" speakers of "Englishes", as well as the ever increasing contact between the speakers of "Englishes" in fields such as education, commerce, culture, and the like, it seems warranted to make the comparison between the pragmatic production of so-called non-native speakers of "Englishes." This study is a small attempt in this direction: to provide a descriptive account of the apology strategies used by Iranian EFL and Malaysian ESL learners. This study is crystallized around two following research questions:

1).How do apology strategies resemble and differ between Iranian EFL and Malaysian ESL learners in terms of typology in English?

2).How do apology strategies resemble and differ between Iranian EFL and Malaysian ESL learners in terms of frequency in English?

\section{Review of Relevant Literature}

The significance of pragmatics has been stressed in the domain of language learning from 1980s. Pragmatics is the study of how people comprehend and produce a communicative act or speech act in a speech situation. People in different countries may view pragmatics principles quite differently from each other, which pave the way for studies in cross-cultural and interlanguage pragmatics. 
As a domain within second language studies, pragmatics is usually referred to as interlanguage pragmatics (ILP), as anology with interlanguage grammar, interlanguage phonology, and the interlanguage lexicon (Kasper \& Rose, 2002). Interlanguage pragmatics investigates the learners' development and use of pragmatic knowledge in second language (L2) contexts. In other words, it examines non-native speakers' comprehension, production, and acquisition of linguistic action in L2, or put briefly, ILP investigates how to do things with words in a second language (Kasper, 1998: 184). The study of Interlanguage Pragmatics (ILP) has been touched on widely in the area of second or foreign language acquisition.

Interlanguage pragmatics encompasses some subfields such as speech acts, implicature, routines and so on. Due to the significant importance of speech acts in second language acquisition and use, the focus of this study is on apology speech act. Studies on speech acts have revealed that the same speech act might be realized quite differently across different cultures (Han, 1992). According to Wolfson (1981), "speech acts differ cross-culturally not only in the way they are realized but also in their distribution, their frequency of occurrence, and in the functions they serve". (p.123). besides, it is of the essence to know how speakers in a language community use speech acts in a variety of social contexts.

The different approaches to investigate the speech act of apology can be divided into three categories: (1) cross-cultural, (2) single language, or (3) interlanguage pragmatic approach. The concern of this study is just on interlanguage pragmatic studies.

\subsection{Interlanguage Studies on Apology}

Unlike cross-cultural and single language studies of apology, studies of interlanguage apologies primarily concentrate on language learners' production of the target language as a second or foreign language.

Trosborg (1987) did the comparison of the speech act of apology between Danish learners of English and native English speakers through role-plays. The results demonstrated that learners of English notably are dissimilar from native English speakers in their use of modality markers.

By means of a DCT, Cordella (1991) investigated the different use of frequency, distribution and function of apology strategies for the comparison of apology strategies in English for Chileans and Australians. The results indicated that there were no significant differences in the frequency of apology strategies but one social factor (gender) notably affected the use of apology in both groups.

In the same line, using verbal DCTs, Linnell, Porter, Stone and Chen (1992) examined the use of apologies. Although their focus was on finding the difference between non-natives and natives in English apology situations, no differences were found between non-native and native speakers in six out of eight apology situations.

By means of a DCT and assessment questionnaire (5 point-rating scale), Bergman and Kasper (1993) investigated Thai and English speakers' perceptions of a committed offense and the choice of apology strategies within a variety of contexts. The results showed that when the speaker is closer to the interlocutor, the offender accepts more responsibility for the offensive act.

In line with Bergman and Kasper's (1993) study, Maeshiba et al. (1996) observed the pragmatic transfer from Japanese to English. He investigated whether pragmatic transfer is influenced by contextual factors or by learners' proficiency level. His participants were four groups (30 Japanese learners of English (Intermediate) JEI, 30 Japanese learners of English (Advanced) JEA, $30 \mathrm{~J}, 30 \mathrm{E}$ ) who completed a DCT incorporating the social perspective. The results showed that the intermediate group transferred their apology behavior from Japanese to English more than the advanced group. This study contrasts Takahashi and Beebe (1987) in that advanced learners transferred more negative pragmatic.

Kim (2001) analyzed Korean and EFL speakers' apology behaviors in terms of different social variables with particular attention to pragmatic transfer of firs language norms. The findings of his study demonstrated the influence of social factors: social distance, social status, age, gender and severity of offense. In regard to the "social status" factor, EFL speakers transferred their L1 pragmatic norms into English when using the "alerter" strategy. With respect to the "age" factor, EFL speakers in the Equal -age group showed the transfer phenomenon from their native pragmatic norms to English. Finally, concerning the "gender" factor, EFL speakers in the male-female group also transferred L1 pragmatic norms by using a higher proportion of the "repetition" strategy than he remaining groups.

It is worth mentioning that substantive claims about the universality of pragmatic principles across cultures and languages should await further research applied in as many new contexts as possible. As Blum-kulka, House and Kasper (1989) also point out, studies of speech acts call for moving away from western cultures to include as many non-western cultures in their scope of study as possible. 
The present study is a response to such a call. It intends to extract and categorize the type and frequency of strategies in the speech act of apologizing among Iranians and Malaysians (two non-western cultures). As such, due to the insufficient literature concerning the non-natives' production of apology speech acts, especially in the case of the comparative studies among Iranians and Malays, the direction of this study goes to this domain.

\section{Methodology:}

\subsection{Participants}

Thirty participants took part in this study: fifteen Iranian and fifteen Malaysian university students studying in different academic fields at Malaysian universities of Putra, Kebangsaan and Malaya. They were selected based on their performance on the TOEFL proficiency test. The rationale behind choosing university students as a source of data collection was a convenience of sampling as well as following from most of the prior studies on speech acts in which the participants had been university students.

\subsection{Procedure}

The data in this study were collected through a Discourse Completion Test (here-after DCT). The DCT used in this study included a brief description of the situations and one participant dialogue. In other words, the questionnaire consisted of 12 fixed discourse situations, which a university student is likely to encounter in his/her daily language interactions. The students reading each situation were then supposed to identify themselves with the persons committing the offenses in the situations and write down their normal language reaction in such situations.

\subsection{Data Analysis:}

The model used in this study for data classification has been based on Cohen and Olshtain (1981: 113-134) and Olshtain and Cohen (1983: 22-23), as well as on the CCSARP coding manual (Blum-Kulka et al., 1989: 289). The data were analyzed by two raters (researchers themselves) and inter-rater-reliability was established through consensus $(\mathrm{r}=.85)$.

(1) Illocutionary Force Indicating Devices (IFIDs)

a. An expression of regret, e.g. I'm sorry

b. An offer of apology, e.g. I apologize

c. A request for forgiveness, e.g. Excuse me/Forgive me/ Pardon me

(2) Explanation or Account

Any external mitigating circumstances, 'Objective' reasons for the violation, e.g. The traffic was terrible

(3) Taking on responsibility

a. Explicit self-blame, e.g. It is my fault/ my mistake

b. Lack of intent, e.g. I didn't mean it

c. Expression of self-deficiency, e.g. I was confused/I didn't see you/ I forgot

d. Expression of Embarrassment, e.g. I feel awful about it

e. Self- dispraise, e.g. I'm such a dimwit!

f.Justify hearer, e.g. You're right to be angry

g. Refusal to acknowledge guilt

Denial of responsibility, e.g. It wasn't my fault

Blame the hearer, e.g. It's your own fault

Pretend to be offended, e.g. I'm the one to be offended

(4) Concern for the hearer, e.g. I hope I didn't upset you/ Are you all right?

(5) Offer of Repair, e.g. I'll pay for damage

(6) Promise of Forbearance, e.g. It won't happen again

\section{Results}

The data in the table 1 represent the various patterns of apology strategies used by both Iranians and Malaysians in all twelve situations.

As far as research question one is concerned, the present study aimed to provide a descriptive picture of the typology of apology strategies that Iranian and Malaysian students display in dealing with identical apology situations. Examining the typology of the strategies revealed some similarities and differences in Iranians and Malaysians' tendencies towards utilization of apology strategies. From among seventeen types of strategies on the DCT, Iranian participants and Malaysian participants used fifteen and eleven types of strategies, respectively. In other words, Iranians and Malaysians used similar types of strategies in many of the situations (eleven). However, Iranians used four more strategies which were not observed in Malaysians' performance. It should be highlighted that the four strategies exclusively used by Iranians happened to have a very low frequency of occurrence and next to negligible. 
As for research question 2, the possible similarities and differences in the frequency of occurrence of the strategies between Iranian and Malaysian participants has been the point of investigation. The findings showed that there are statistically significant differences and similarities in terms of the frequency of strategies used by Iranian and Malaysian respondents.

As indicated in the table 1, in certain situations Iranians and Malaysians have had similar tendencies in utilization of apology strategies. "A request for forgiveness", "explicit self-blame", "self-dispraise", "refusal to acknowledge guilt" and "promise of forbearance" are the strategies with almost similar frequency of occurrence among Malaysians and Iranians. For instance, for both Iranians and Malaysians the use of IFID 'I'm sorry' garnered the highest percentage of use (34\% for Iranians and 39\% for Malays).

However, in some other situations the frequency of strategies has been considerably discrepant. "An expression of regret", "an offer of apology", "explanation", "lack of intent", "expression of self-deficiency", "concern for the hearer", and "offer of repair" have been the strategies with a different frequency of occurrence among Iranians and Malaysians. For example, whereas "An offer of apology' is the second most frequently-used strategy among Iranians (13\%), “offer of repair' has ranked second among Malay participants.

\section{Discussion}

As stated above, in eleven (out of 17) situations Iranian and Malaysian students utilized the same typology of strategies; however, Iranians used four more types of strategies which were not observed in Malaysians' performance. What was more interesting was the low frequency of the four Iranian-specific typologies which was next to negligible. This identicality in opting for the same typologies of strategies among the majority of the participants could be attributed to the more or less same language proficiency of participants. The negligible typological differences in using apology strategies might be ascribed to the individual differences, especially personality-related style preferences, and also language-learner strategies in pragmatic performance. Cohen (2008) in this respect asserts that there exist factors on the learners' side which may uphold or impede their ability to perform speech acts in ways that are appropriate for the given situations in which they find themselves (e.g., their language proficiency, learning style preferences, and personality).

The differences in the frequency of apology can be attributed to respondents' different cultural values and norms because language is so much associated with its culture, and naturally there would be some difficulties in acquiring the nuances in language that are so culture-bounded. Therefore, this may result in different frequency of the use of pragmatic strategies, especially speech acts strategies among various cultures.

In terms of similarities, Iranian and Malaysian societies, as two non-western countries, are reported to be traditionally non-egalitarian societies as opposed to American as a super-egalitarian society (Beeman, 1988). Thus, a speaker chooses his/her strategy based on the hierarchical differences (e.g. social status, social distance) between the speaker and his/her hearer. In other words, their choice of strategy depends on whether they are apologizing to a professor, a classmate, a teacher, a close friend, or a stranger. Observing the hierarchy factor, they made use of similar strategies in a variety of social contexts.

The use of " an expression of regret" and " an offer of apology" as the first and second most frequently used strategies respectively, by Iranian learners can be attributed to respondents' L2 apology development which commences with the formulaic stage. The emergence of other strategies in the later development stage may indicate that in addition to linguistic features of apology strategies, other factors such as the saliency of the strategy in performing the apology or instruction also determine the choice of the strategy. The expression "I'm sorry/sorry" is the most essential strategy in the apology speech act, which was evidenced by the findings of the present study and several other studies (e.g., Bardovi-Harlig et al., 2008; Olshtain and Cohen, 1983; Rintell and Mitchell, 1989; Trosborg, 1995) showing that it is the most commonly used apology strategy, and therefore is acquired earlier. The "request for forgiveness" strategy, on the other hand, may only be required for the situations with higher severity of offense. Trosborg (1995) also discovered that the "forgiveness" strategy was less frequently used by both the native speaker group and the non-native speaker groups among IFID strategies.

Regarding the Malaysians' strategy use, their use of "expression of regret" as the first most frequently used strategy, "offer of repair" as the second and "explanation" as the third strategy can be attributed to the negative impact of their L1 linguistic and sociocultural rules on the sociopragmatic competence in the production of apologies in English. Additionally, it stems from the rules of speaking in Malay owing to the fact that traditionally, the Malays value indirectness in speaking as to save face of others and maintaining good relationship among the interlocutors and the society as whole. When faced with uncomfortable situations, they will try to control their anger, to avoid saying anything or even deal with those situations face to face (Mustafa ,2002:103-104; Abdullah ,1996:30; Jamaliah , 1995:34).This is because, in the Malay culture, sometimes the show of tolerance and understanding via silence and 
avoidance of responses are valued more than objective and rational excuses. These are all due to the emphases in being cultured and refined.Discontent, if expressed, will be done indirectly so as to avoid overt confrontation and arouse feelings of discomfort in the other party. This explains why Malays are more inclined to state what should be said rather than say what they really feel.

\section{Conclusions}

The findings of this study, though small in scale, suggest that the pragmatic performance of students hinges on certain factors other than language proficiency. The participants were of more or less the same level of proficiency, however in certain cases they dealt with identical apology situations quite differently. For example, Malaysian students resorted to fewer strategies in apologizing in comparison with their Iranian counterparts. Such discrepancies might be attributed to a host of factors such as socio-economic and sociocultural backgrounds of the students, negative transfer of pragmatic norms from their L1, the EFL/ESL status of the learners, to name a few. Typologically speaking, the differences between Iranian and Malays are attributable to mostly the characteristics of the given respondents such as learning style preferences, test-taking strategy preferences and personality.

\section{Limitations and suggestions for future research}

First and foremost, the size of the population was small and the participants were solicited from the university students majoring in different academic fields, namely, postgraduate students at three Malaysian universities. Therefore, hardly can the findings be generalized beyond this group. One can broaden the results by incorporating other participants out of the academic context. Secondly, the data were collected through a DCT; therefore, it can be hardly claimed that the collected data are exactly the same as naturally occurring interactional data, in that what one claims to do in a given situation is not necessarily the same as what one may actually do in a real life situation. Capitalizing on diaries (self-reports) and ethnographic observation could be methodologically reliable ways of collecting authentic data. Thirdly, the situational factors (Social power, social distance and imposition) were not considered in the analysis of the results. Last but not least, in this study gender of the participants and the residency duration of Iranian students in Malaysian context were not considered, therefore it is suggested that the future studies should take care of such variables.

\section{References}

Abdullah, A. (1996). Going Glocal: Cultural Dimension in Malaysian Management. Kuala Lumpur: MIM.

Bardovi-Harlig, K. (2001). Evaluating the empirical evidence: grounds for instruction in Pragmatics. In K. R. Rose \& G. Kasper (Eds.), Pragmatics in Language Teaching. New York: Cambridge University Press.

Bardovi-Harlig, K. , Rose, M., \& Nickels, E. L. (2008). The use of conventional expressions of thanking, apologizing, and refusing. In Bowles, M. et al. (Eds), Selected Proceedings of the 2007 Second Language Research Forum. Cascadilla Proceedings Project, Somerville, MA, pp. 113- 130.

Beeman, W. O. (1988). Affectivity in Persian Language Use. Culture, Medicine and Psychiatry, 12, 9-30.

Bergman, M. \& Kasper, G. (1993). Perception and performance in native and nonnative apology.In: Kasper, G. and Blum-Kulka, S. (Eds.), Interlanguage Pragmatics. (pp.82-107). New York, NY: Oxford University Press.

Blum-Kulka, S., House, J., \& Kasper, G. (Eds.). (1998). Cross-cultural Pragmatics: Request and apologies. Advances in Discourse Processes. Vol 31, Norwood, NJ: Ablex Publishing Corporation.

Brown, P. \& Levinson, S. (1987). Politeness: Some universals in language usage. Cambridge: Cambridge University Press.

Cohen, A. . (2008). Teaching and assessing L2 pragmatics: What can we expect from learners? Language Teach, 41,213-235.

Cohen, A. \& Olshtain, E. (1981). Developing a measure of sociolinguistic competence: The case of apology. Language Learning, 31, 113-134.

Cordella, M.(1991). Spanish speakers apologizing in English: A cross-cultural pragmatics study. Australian Review of Applied Linguistics, 14, 115-138.

Goffman, E. (1971). Relations in public: Microstudies of the public order. Harmondsworth: Penguin.

Jamaliah, M. A. (1995). Indirectness in Malay Diplomacy: with particular reference to Business Dealings and Labor Relations, Jurnal Bahasa Moden,9, 19-28.

Kasper, G. (1998). Interlanguage Pragmatics. In H. Byrnes (Ed.),Learning Foreign and Second Languages: Perspectives in Research and Scholarship (PP.183-208). New York: The Modern Language Association of America. 
Kasper, G. \& Rose, K. R. (2002). Pragmatic development in a second language. Michigan: Blackwell.

Kim, D, K. (2001). A Descriptive Analysis of Korean and English Apologies with Implications for Interlanguage Pragmatics. PhD Dissertation, University of Florida.

Linnel, J., Porter, F., Stone, H. \& Chen, W. (1992). Can you apologize me? An investigation of speech act performance among non-native speakers of English. Working papers in Educational Linguistics, 8, 33- 53.

Maeshiba, N., yoshinaga,N., Kasper,G., \& Ross, S. (1996). Transfer and proficiency in interlanguage apologizing. In Gass,S. \& Neu, J.(Eds.), Speech acts across cultures: Challenge to communication in a second language. (pp. 155- 187).Berlin: Mouton.

Mustafa, D. (2002). Budi Bahasa dalam tamadun Melayu dan Tamadun Islam: Satu perbandingan. In Syed Muhammad Dawilah al-Edrus (ed.), Pemikiran Melayu tentang alam dan hakikat Diri, 99-122. Kuala Lumpur: DBP.

Olshtain, E. \& Cohen, A. (1983). Apology: A speech act set. In Wolfson, N.\& Judd, E.(Eds.), Sociolinguistics and Language acquisition. (pp.18- 35.)Rowley,MA: Newbury House.

Rintell, E. \& Mitchell,C. (1989). Studying requests and apologies: an inquiry into method. In :Blum-Kulka, S., House, J., \& Kasper, G. (Eds.),Cross-cultural Pragmatics: Requests and Apologies. (pp. 248-273).Ablex Publishing Corporation: Norwood.

Trosborg, A. (1987). Apology strategies in natives/non-natives. Journal of Pragmatics, 11, $144-67$.

Trosborg, A. (1995).Interlanguage Pragmatics: Requests, Complaints, and Apologies. Moutonde Geuyter, Berlin.

Wolfson, N. (1983). Rules of Speaking. In Richards, J. C. \& Schmidt, R. W. (Eds.). Language and Communication, 61-87.

Wouk, F. (2006). The language of apologizing in Lombok, Indonesia. Journal of Pragmatics, 38, 1457-1486.

Table 1.

\begin{tabular}{|c|c|c|}
\hline (1)Illocutionary Force Indicating Device & Iranians & Malaysians \\
\hline a. An expression of regret & $107 / 34 \%$ & $172 / 39 \%$ \\
\hline b. An offer of apology & $40 / 13 \%$ & $2 / \quad \mathbf{0 . 5 \%}$ \\
\hline c. A request for forgiveness & $29 / 9 \%$ & $24 / 6 \%$ \\
\hline (2)Explanation or Account & $23 / 7 \%$ & $54 / 12 \%$ \\
\hline (3)Taking on responsibility & & \\
\hline a. Explicit self-blame & $17 / 5 \%$ & $16 / 4 \%$ \\
\hline b. Lack of intent & $13 / 4 \%$ & $26 /$ \\
\hline 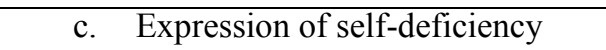 & $24 / 8 \%$ & $43 / \quad 10 \%$ \\
\hline d. Expression of Embarrassment & $4 / 1 \%$ & $\mathbf{0}$ \\
\hline e. Self-dispraise & $\mathbf{0}$ & $1 / \quad 0.20 \%$ \\
\hline f. Justify hearer & $3 / 1 \%$ & $\mathbf{0}$ \\
\hline $\begin{array}{ll}\text { g. } & \text { Refusal to acknowledge guilt }\end{array}$ & & $\mathbf{0}$ \\
\hline - $\quad$ Denial of responsibility & $3 / 1 \%$ & $\mathbf{0}$ \\
\hline - $\quad$ Blame the hearer & $8 / 3 \%$ & $\mathbf{0}$ \\
\hline - $\quad$ Pretend to be offended & $4 / 1 \%$ & $\mathbf{0}$ \\
\hline (4)Concern for the hearer & $6 / 2 \%$ & $15 / 3 \%$ \\
\hline (5)Offer of Repair & $27 / 9 \%$ & $77 / 18 \%$ \\
\hline (6)Promise of Forbearance & $2 / \quad 1 \%$ & $4 / \quad 1 \%$ \\
\hline
\end{tabular}

